\title{
Promotion of ovarian cancer cell invasion, migration and colony formation by the miR-21/Wnt/CD44v6 pathway
}

\author{
YANQING WANG, XIAO YANG, MENGQIN YUAN, SHU XIAN, \\ LI ZHANG, DONGYONG YANG and YANXIANG CHENG
}

\begin{abstract}
Department of Obstetrics and Gynecology, Renmin Hospital of Wuhan University, Wuhan, Hubei 430060, P.R. China
\end{abstract}
Received November 23, 2018; Accepted April 24, 2019

DOI: 10.3892/or.2019.7153

\begin{abstract}
Ovarian cancer (OC) has the highest mortality rate among female malignant tumors, and OC commonly relapses and metastasizes. The mechanisms underlying the occurrence and development of ovarian cancer are numerous and complicated. The aim of the present study was to explore an important molecular mechanism that may provide a theoretical basis for the clinical treatment of ovarian cancer. In the present study, the expression level of miR-21 was analyzed in clinical specimens, normal ovarian epithelial cells and three different ovarian cancer epithelial cell lines. Then, in vitro experiments were performed following the transient transfection of miR-21 mimics and inhibitors into SKOV3 cells. RT-PCR, western blot analysis, colony formation assay, and Transwell migration and invasion assays were used to explore the role of miR-21 in ovarian cancer. In addition, Wnt signaling pathway inhibitors and activators were used to validate the hypothesis that the miR-21/Wnt/CD44v6 pathway plays an important role in OC. In ovarian cancer tissues and cells, miR-21 was highly expressed, and the high expression of miR-21 could activate the Wnt signaling pathway to regulate the expression of CD44v6 and affect the proliferation, invasion and migration of OC cells. miR-21 regulated the expression of CD44v6 by activating the Wnt signaling pathway, which plays an important role in the development of ovarian cancer. These findings provide a potential new therapeutic target for the clinical diagnosis and treatment of ovarian cancer.
\end{abstract}

\section{Introduction}

Ovarian cancer (OC) is the gynecologic tumor with the highest mortality rate, and the incidence of $\mathrm{OC}$ is increasing each year (1). Usually, OC is discovered at a late stage; thus,

Correspondence to: Dr Yanxiang Cheng, Department of Obstetrics and Gynecology, Renmin Hospital of Wuhan University, Wuhan, Hubei 430060, P.R. China

E-mail: doctornancy@qq.com

Key words: ovarian cancer, miRNA21, Wnt signaling pathway, CD44v6 the clinical diagnosis is usually advanced. At present, the primary clinical treatment method for ovarian cancer is combined surgery, radiotherapy and chemotherapy. However, the treatment effect is not ideal, and resistance and relapse are common. The 5-year survival rate of patients is only $20-30 \%$ (2). Therefore, if a molecular biological pathway related to treatment resistance in refractory ovarian epithelial cancer can be discovered, it may be possible to identify new therapeutic targets and administer individualized treatment to improve the prognosis of patients.

MicroRNAs (miRNAs) are noncoding single-stranded small-molecule RNAs with regulatory functions that inhibit the degradation or translation of target mRNAs by complementarily binding to those mRNAs (3). miRNAs have become a hotspot in medical research in recent years, and these regulatory molecules have exhibited great potential as therapeutic targets and regulatory factors of tumors (4-6). It is estimated that up to $90 \%$ of human genes are regulated by miRNAs, and >3,700 miRNAs have been identified in human cells $(7,8)$. MicroRNA-21 (miR-21) has been revealed to be overexpressed in most epithelial cancers and is believed to play a pivotal role in the progression of many malignancies, including lung, breast, stomach, prostate, colon, brain, head and neck, esophagus and pancreatic cancers (9). In addition, studies have revealed that the knockdown of miR-21 impairs growth, induces apoptosis and reduces the migration and invasion of cancer cells (10).

The Wnt/ $\beta$-catenin signaling pathway, which is one of the most relevant pathways involved with cancer stem cells, has been reported to be aberrantly activated in various types of cancers, including ovarian cancer (11-14). Among the Wnt signaling pathways, which include the classical Wnt/ $\beta$-catenin signaling pathway, the Wnt/PCP signaling pathway and the Wnt $/ \mathrm{Ca} 2^{+}$signaling pathway, the classical $\mathrm{Wnt} / \beta$-catenin signaling pathway is the most relevant to cancer (15). In normal stem cells, the function of the Wnt/ $\beta$-catenin signaling pathway is to regulate cell proliferation, self-renewal, migration and apoptosis. In cancer stem cells, the Wnt/ $\beta$-catenin signaling pathway plays a pivotal role, as well. It is known that the $\mathrm{Wnt} / \beta$-catenin pathway is one of the major signaling pathways involved in the epithelial-mesenchymal transition. Chau et al (16) reported that c-Kit regulates ovarian cancer stem cells through the activation of $\mathrm{Wnt} / \beta$-catenin signaling. However, the mechanism through which miR-21 and Wnt/ $\beta$-catenin signaling regulate ovarian cancer cells has 
not been thoroughly elucidated to date. Many studies have confirmed that miRNAs activate $\mathrm{Wnt} / \beta$-catenin signaling in tumor tissues and cells. miR135a/b is an oncogenic miRNA that suppresses APC directly to promote the activation of the $\beta$-catenin pathway in colorectal cancer (17). Luo et al (18) showed that $\beta$-catenin may be an important downstream target gene of miR-21 and Sox 2 and is involved in the regulation of the migration and invasion of human glioma. These findings raise the question of whether miR21 also regulates the Wnt signaling pathway in ovarian cancer. CD44 is a molecule that is located in the cell membrane and consists of an extracellular domain, a transmembrane domain and a cytoplasmic domain. The extracellular domain of CD44 contains an N-terminal globular domain and a proximal stalk membrane region. A subfamily of CD44 splice variants encompassing the variant domain $6(\mathrm{CD} 44 \mathrm{v} 6)$ has been implicated in the metastatic potential of tumors (19-21). CD44 isoforms containing CD44v6 (isoforms v4-7 and v6-7) were revealed to confer metastatic potential on nonmetastatic tumor cell lines in a syngeneic rat tumor model (19). Numerous studies have revealed that CD44v6 is highly expressed in OC tissues and is associated with drug resistance in OC $(22,23)$. In addition, studies have shown that CD44v6 is a target gene of the Wnt signaling pathway (24); thus, we hypothesized that miRNA21 may influence the expression level of CD44v6 in OC cells through the Wnt signaling pathway, thereby affecting the proliferation, invasion and migration of OC cells; we further hypothesized that miRNA21 may even affect the prognosis of patients with OC. Our hypothesis was confirmed using miRNA21 analogs, inhibitors and agonists of the Wnt signaling pathway.

\section{Materials and methods}

Clinical sample collection. A total of 35 specimens of benign ovarian tumors and 40 specimens of malignant tumors were collected from January 2017 to December 2017 at Renmin Hospital of Wuhan University (Wuhan, China). The age range of patients was 35-65 years of age and had no other tumors. All patients reviewed the content and purpose of the study and provided written informed consent. All patients knew and agreed to participate in the study prior to specimen collection. The project was approved by the Medical Ethics Committee of Renmin Hospital of Wuhan University. All ovarian tumor tissues were pathologically confirmed as epithelial ovarian cancer. Prior to the acquisition of the tissue, the patients did not undergo any tumor-related treatments, such as chemotherapy, radiation therapy or immunotherapy.

Cell culture. SKOV3, A2780 and OVCAR3 cells are human serous OC cell lines that were obtained from the American Type Culture Collection (ATCC; Manassas, VA, USA) cell bank. IOSE80, a normal ovarian epithelial cell line, was also obtained from the ATCC cell bank. The cell culture medium was DMEM/F12 (cat. no. SH30023.01; HyClone; GE Healthcare Life Sciences) supplemented with $10 \%$ fetal bovine serum (FBS; cat. no. 141215; Hangzhou Tianhang Biological Technology Co., Ltd., Hangzhou, China) and $1 \%$ anti-cyanin. Cells were grown in a cell culture flask in a humidified incubator at $37^{\circ} \mathrm{C}$ in an atmosphere composed of $95 \%$ air and $5 \%$ carbon dioxide. The medium was changed every
2 days. Cells were passaged using $0.05 \%$ trypsin/ethylenediaminetetraacetic acid (cat. no. GNM25200; Gino Biomedical Technology Co., Ltd., Hangzhou, China). A Wnt inhibitor (XAV-939; cat. no. S1180; Selleck Chemicals, Houston, TX, USA) and a Wnt agonist (AZD2858; cat. no. HY-15761; Medical Chemical Corp., Torrance, CA, USA) were added at a concentration of $1 \mu \mathrm{M}$ for $12 \mathrm{~h}$.

Cell transfection. The cells were seeded at a density of $4 \times 10^{5}$ cells/well in 24 -well culture plates containing the appropriate amount of complete medium to achieve a cell density of $30-50 \%$ at the time of transfection. The specific miR-21 mimics/inhibitor and the negative control (NC) were designed and purchased from GenePharma Co., Ltd. (Shanghai, China). The sequences of the miRNA mimics and inhibitor are as follows: hsa-miR-21-5p mimics: UAGCUU AUCAGACUGAUGUUGA, AACAUCAGUCUGAUAAGC UAUU; hsa-miR-21-5p inhibitor UCAACAUCAGUCUGA UAAGCUA; miRNA control UUCUCCGAACGUGUCACG UTTACGUGACACGUUCGGAGAATT. Cells were collected for further analysis after $48 \mathrm{~h}$ of transfection.

Western blot analysis. Total protein was extracted from adherent cells as follows: First, the adherent cells were washed 2-3 times with PBS buffer. Then, the appropriate volume of total cell protein extraction reagent (RIPA protein lysate; cat. no. AS1004; Aspen) (with protease inhibitors added within minutes of use) was added to the culture plates/vials for 3-5 min. Next, the cells were collected into 1.5-ml centrifuge tubes and incubated in an ice bath for $30 \mathrm{~min}$ with repeated pipetting to ensure the complete cell lysis. After centrifugation at $13,000 \mathrm{x} \mathrm{g}$ for $5 \mathrm{~min}$ at $4^{\circ} \mathrm{C}$, the supernatant was collected, which contained the total protein solution. The protein concentration of each sample was determined using a BCA protein concentration assay kit (cat. no. AS1086; Aspen). A total of $30 \mu \mathrm{g}$ of protein was loaded onto $10 \%$ SDS-polyacrylamide gels, separated and then transferred onto polyvinylidene difluoride membranes (PVDF; Bio-Rad Laboratories, Inc., Hercules, CA, USA). Then $5 \%$ milk blocking solution was incubated for $2 \mathrm{~h}$ at room temperature. The membranes were probed with primary antibodies against human CD44V6 (dilution 1:10,000; cat. no. ab78960; Abcam, Cambridge, UK), $\beta$-catenin (dilution 1:10,000; cat. no. ab32572; Abcam) and GAPDH (dilution 1:2,000; cat. no. ab37168; Abcam) at $4^{\circ} \mathrm{C}$ overnight. After several washes with TBST, the membranes were incubated with HRP-conjugated goat anti-mouse (dilution 1:10,000; cat. no. AS1106; Aspen) or HRP-conjugated goat anti-rabbit (1:10,000; cat. no. AS1107; Aspen) at room temperature for $2 \mathrm{~h}$. The bound antibody was detected using the SuperSignal West Pico ECL Chemiluminescent Kit (Thermo Fisher Scientific, Inc., Rockford, IL, USA).

Quantitative real-time polymerase chain reaction ( $q R T-P C R$ ). Total RNA from tissues and cells was isolated using TRIzol reagent (cat. no. 15596-026; Invitrogen ${ }^{\mathrm{TM}}$; Thermo Fisher Scientific, Inc., Watham, MA, USA) according to the manufacturer's instructions. Next, $250 \mu \mathrm{l}$ of chloroform was added, mixed well, and incubated on ice for $5 \mathrm{~min}$. Then, the samples were centrifuged at $10,000 \mathrm{x}$ g for $10 \mathrm{~min}$ at $4^{\circ} \mathrm{C}$. In an ultraclean workbench, $400 \mu 1$ of the supernatant was 
carefully absorbed into a 1.5-ml EP tube, and an equal volume of $4^{\circ} \mathrm{C}$ precooled isopropanol was added. Then, the samples were mixed by inversion and incubated at $-20^{\circ} \mathrm{C}$ for $15 \mathrm{~min}$. Next, the samples were centrifuged at $10,000 \mathrm{x} \mathrm{g}$ for $10 \mathrm{~min}$ at $4^{\circ} \mathrm{C}$, after which the liquid was carefully decanted. Then, $1 \mathrm{ml}$ of precooled $\left(4^{\circ} \mathrm{C}\right) 75 \%$ ethanol was added, and the tubes were inverted several times to wash the RNA precipitate. Subsequently, the tubes were centrifuged at $4^{\circ} \mathrm{C}$ at $10,000 \times \mathrm{g}$ for $5 \mathrm{~min}$, after which the liquid was decanted. Finally, the samples were dried on a clean table for several minutes to fully evaporate the ethanol, and then $10 \mu \mathrm{l}$ of RNase-Free Water was added to fully dissolve the RNA.

cDNA synthesis was performed using the M-MLV reverse transcriptase kit (Invitrogen ${ }^{\mathrm{TM}}$; Thermo Fisher Scientific, Inc.). Briefly, the following reagents were added into an EP tube: $1 \mu l$ of the internal reference gene-specific reverse transcription primer $(10 \mu \mathrm{M}), 1 \mu \mathrm{l}$ of the target gene-specific reverse transcription primer $(10 \mu \mathrm{M}), 1 \mu \mathrm{l}$ of the dNTP mix, and $10 \mu \mathrm{l}$ of RNA. The samples were incubated at $65^{\circ} \mathrm{C}$ for $5 \mathrm{~min}$ and then on ice for $2 \mathrm{~min}$. Next, $4 \mu \mathrm{l}$ of the $5^{\prime}$ first strand synthesis buffer and $2 \mu \mathrm{l}$ of $0.1 \mathrm{M}$ DTT were added into the EP tube, which was incubated in the PCR instrument at $37^{\circ} \mathrm{C}$ for $2 \mathrm{~min}$. Finally, $1 \mu \mathrm{l}$ of M-MLV reverse transcriptase was added, and the tubes were placed in the PCR instrument and subjected to $37^{\circ} \mathrm{C}$ for $50 \mathrm{~min}$, followed by $75^{\circ} \mathrm{C}$ for $15 \mathrm{~min}$. Then, the samples were cooled to $4^{\circ} \mathrm{C}$.

qRT-PCR analysis of the RNA was performed using the Qiagen OneStep RT-PCR kit (Qiagen, Inc., Valencia, CA, USA). Total RNA was polyadenylated and reverse-transcribed using the TaqMan MicroRNA Reverse Transcription kit and TaqMan miRNA assay (Applied Biosystems; Thermo Fisher Scientific, Inc.) according to the manufacturer's instructions. The expression of U6 (a small nuclear RNA) was used as the internal control. The relative expression of the tested genes was calculated and normalized using the $2^{-\Delta \Delta \mathrm{Cq}}$ method (25). RT-PCR was performed on a Life Technologies StepOne ${ }^{\mathrm{TM}}$ Real-Time PCR instrument using the SYBR ${ }^{\circledR}$ Premix Ex Taq ${ }^{\mathrm{TM}}$ kit (Takara Bio Inc., Otsu, Japan). Each sample was tested in triplicate. The amount of each reagent was as follows: $5 \mu 1$ of 2X qPCR Mix, $1 \mu \mathrm{l}$ of primer working solution $(2.5 \mu \mathrm{M})$, $1 \mu \mathrm{l}$ of template, $2.8 \mu \mathrm{l}$ of $\mathrm{ddH}_{2} \mathrm{O}$, and $0.2 \mu \mathrm{l}$ of Rox dye. The following primers were used: U6 RT primer, 5'-AACGCTTCA CGAATTTGCGT-3', forward, 5'-CTCGCTTCGGCAGCA CAT-3' and reverse, 5'-AACGCTTCACGAATTTGCGT-3'; hsa-miR-21 RT primer, 5'CTCAACTGGTGTCGTGGAGTC GGCAATTCAGTTGAGTCAACATC-3', forward, 5'-TGG GCTTATCAGACTGATGTTGA-3 and reverse 5'-CTCAAC TGGTGTCGTGGAGTC-3'; H-GAPDH forward, 5'-CATCAT CCCTGCCTCTACTGG-3' and reverse, 5'-GTGGGTGTC GCTGTTGAAGTC-3'; H- $\beta$-catenin forward, 5'-GCCAAG TGGGTGGTATAGAGG-3' and reverse, 5'-GGGATGGTG GGTGTAAGAGC-3'; H-CD44V6 forward, 5'-GCCTTTGAT GGACCAATTACC-3' and reverse, 5'- TCATTCCTATTG GTAGCAGGGA-3'.

Colony formation assay. Cells in the logarithmic growth phase were digested with $0.25 \%$ trypsin. Then, the cells were suspended in DMEM medium containing $10 \%$ fetal bovine serum. The cell suspension was diluted and seeded at a density of 1,000 cells/well in a dish containing $10 \mathrm{ml}$ of $37^{\circ} \mathrm{C}$ prewarmed culture medium. The dish was gently rotated to uniformly disperse the cells. The cells were incubated at $37^{\circ} \mathrm{C}$ with $5 \% \mathrm{CO}_{2}$ and saturated humidity for 2 to 3 weeks. When macroscopic clones appeared in the culture dish, the culture was terminated. The supernatant was discarded, and the cells were carefully washed twice with PBS. Then, $4 \%$ paraformaldehyde was used to fix the cells for $15 \mathrm{~min}$. Subsequently, the appropriate amount of GIEMSA application staining solution was added to the fixative solution for 10 to $30 \mathrm{~min}$. Subsequently, the staining solution was slowly washed away with running water, and the plate was allowed to air dry. The plate was inverted and overlaid with a grid of transparencies, and the clones were counted directly with the naked eye; alternatively, the number of clones $>10$ cells was counted under a light microscope (low magnification). Finally, the clone formation rate was calculated as follows: Clonal formation rate $=($ no. of clones/no. of cells inoculated) $\times 100 \%$.

Transwell migration and invasion assay. The dyeing solution was prepared as follows: $0.5 \%$ crystal violet solution diluted 1:5 with PBS solution was added into the $0.01 \%$ crystal violet dye solution. The cells were prepared into a suspension of $10^{5}$ cells $/ \mathrm{ml}$, and $1 \mathrm{ml}$ of the cell suspension was centrifuged at $10,000 \mathrm{x} \mathrm{g}$ for $5 \mathrm{~min}$, after which the supernatant was discarded. Then, $1 \mathrm{ml}$ of serum-free medium was added and mixed evenly, after which $200 \mu$ l of the cell suspension was added into the Transwell chamber. Next, $500 \mu 1$ of complete medium containing $10 \%$ FBS was added to the 24-well plate, and the chamber was placed in the plate. The plate was incubated for $48 \mathrm{~h}$ at $37^{\circ} \mathrm{C}$ in an incubator with $5 \% \mathrm{CO}_{2}$. The chamber was then removed, the medium was washed away with PBS, the glue and cells in the upper chamber were wiped clean with a cotton swab, and crystal violet stain was applied for $10 \mathrm{~min}$. Then, the surface crystal violet was washed away, and the side opposite to the cell-inoculation side was photographed under an inverted microscope. The cell invasion assay was performed in an identical manner to the cell migration assay, except that a specific proportion of Matrigel (Serum-free medium: matrigel=7:1) was added to the Transwell chamber.

$C C K-8$. SKOV3 cells in the logarithmic growth phase were digested with trypsin to prepare a cell suspension at a concentration of $1 \times 10^{5}$ cells $/ \mathrm{ml}$, which was seeded in a 96-well plate at 8,000 cells/well and $100 \mu \mathrm{l} /$ well. The plate was incubated at $37^{\circ} \mathrm{C}$ with $5 \% \mathrm{CO}_{2}$ for $24 \mathrm{~h}$ for the cells to adhere. The medium was changed after $24 \mathrm{~h}$. Five replicates were used for each sample concentration. Next, $10 \mu \mathrm{l}$ of CCK-8 solution was added to all wells, and the plate was incubated for $2 \mathrm{~h}$. Finally, the absorbance at $450 \mathrm{~nm}$ was measured using a microplate reader. Then, the cells that were treated with the solvent were used as a control group, and the medium without cells served as the blank group. The survival rate of the cells was calculated according to the following formula:

\section{Cell viability $\%=($ experimental group-blank group)/(control group-blank group) $\mathrm{x} 100 \%$.}

Immunohistochemistry. Following tissue embedding, sectioning, baking, dewaxing, rehydration and antigen retrieval, the blocking solution was added for $1 \mathrm{~h}$. Then, the primary 
antibody, anti-CD44v6 (dilution 1:500; cat. no. ab78960; Abcam), was applied overnight at $4^{\circ} \mathrm{C}$. Next, the sections were washed with PBS, and a secondary antibody goat anti-mouse (dilution 1:200; cat. no. AS1106; Aspen) was added at room temperature for $2 \mathrm{~h}$. Then, the sections were washed 3 times with PBS, and the color developer (DAB) was added. Finally, the sections were rinsed, counterstained and sealed.

Immunofluorescence. The cell suspension was added to a coverslip and incubated at $37^{\circ} \mathrm{C}$ in an incubator with $5 \% \mathrm{CO}_{2}$ until the cells were fixed $(\sim 2 \mathrm{~h})$. The culture was continued for $2 \mathrm{~h}$ with the addition of $2 \mathrm{ml}$ of the cell culture solution. Then, the medium was decanted, and the cells were washed 3 times with PBS. Next, $4 \%$ paraformaldehyde was added for $30 \mathrm{~min}$ to fix the cells, and subsequently the cells were washed three times with PBS. Next, the slides were slightly dried, and 50-100 $\mu \mathrm{l}$ of the DAPI staining solution (cat. no. AS1075; Aspen) was added and incubated for $10 \mathrm{~min}$ at room temperature, followed by 3 washes with PBS. Subsequently, a $3 \%$ hydrogen peroxide solution was added, and the slides were incubated at room temperature for $20 \mathrm{~min}$ in the dark, and then the slides were placed in PBS (pH 7.4) 3 times on a decolorizing shaker. After the slides were slightly dried, the cells were covered with an anti- $\beta$-catenin primary antibody (dilution 1:200; cat. no. ab16051; Abcam) diluted to a specific concentration with 5\% BSA and incubated in a humidified box at $4^{\circ} \mathrm{C}$ overnight. Then, the slides were placed in PBS ( $\left.\mathrm{pH} 7.4\right)$ and washed 3 times on a bleaching shaker. After drying slightly, the cells were covered with a secondary antibody of the corresponding species (CY3-labeled goat anti-rabbit; dilution 1:50; cat. no. AS-1109; Aspen) and incubated for $50 \mathrm{~min}$ at room temperature. Then, the slides were washed 3 times with PBS, and 50-100 $\mu 1$ of DAPI staining solution was added dropwise to each well, followed by incubation for $5 \mathrm{~min}$ at room temperature. Subsequently, PBS was added to each well for 3 washes. An appropriate amount of anti-fluorescence quencher was added dropwise to the cells, the coverslips were mounted, and the slides were observed under a fluorescence microscope.

Statistical analysis. Data are expressed as the mean \pm SEM. Data were analyzed using SPSS 21.0 (IBM Corp., Armonk, NY, USA) software. A t-test was used to compare two groups, and one-way analysis of variance (ANOVA) followed by Bonferroni post hoc test was used to compare multiple groups. The Chi-square test was used to classify the data. A P-value of $\mathrm{P}<0.05$ was considered to indicate a statistically significant difference.

\section{Results}

Expression of miR-21 in benign and malignant ovarian tissue samples. To investigate the expression level of miR-21 in benign and malignant ovarian tissues, the expression level of miR-21 was examined in 35 benign and 40 malignant ovarian tissue samples. The results are presented in Fig. 1A. As anticipated, the expression level of miR-21 in malignant OC tissues was significantly higher than that in benign ovarian tissues (Fig. 1A; $\mathrm{P}<0.01$ ). This finding indicated that miR-21 may play a role in the development of malignant ovarian tumors.
Increased expression of miR-21 in ovarian cancer cell lines. To further investigate the expression of miR-21 in OC cell lines and normal ovarian epithelial cells, the expression levels of miR-21 were examined in the OC malignant cell lines SKOV3, OVCAR3, A2780 and the ovarian normal epithelial cell line IOSE80. The results revealed that the expression level of miR-21 in SKOV3 cells was significantly higher than that in the normal ovarian epithelial cell line (Fig. 1B; $\mathrm{P}<0.01$ ). This trend was consistent with the results of the human tissue samples, indicating that miR-21 may in fact play an important role in malignant OC.

Effect of miR-21 expression on the biological behavior of ovarian cancer cells. To determine whether the expression level of miR-21 affects the biological behavior of OC cells, loss- and gain-of-function experiments were performed in SKOV3 cells using the transient transfection with miR-21 mimics or an inhibitor. The transfection efficiency of RNA oligos was ascertained by qRT-PCR, as revealed in Fig. 1C and the proliferation rate of SKOV3 cells was determined by CCK-8 assay (Fig. 1D). Compared with the negative control group, the proliferation rate in the miR-21-inhibitor group was lower Then, the cell clonal formation, invasion and migration was examined in each group. As observed in Fig. 2A and B, the SKOV3 cell clonal formation rate was similar in the blank control group and the negative group. Although there were no significant differences between the negative control group and the miR-21-mimics group (Fig. 2B, C, and I; P>0.05), the colony formation rate of the SKOV3 cells in the miR-21-inhibitor group was obviously lower than the negative control group (Fig. 2B, D and I; $\mathrm{P}<0.01$ ). Compared with the negative control group, SKOV3 cell migration (Fig. 3B, C and I, $\mathrm{P}<0.01$ ) and invasion (Fig. 4B, $\mathrm{C}$ and $\mathrm{I} ; \mathrm{P}<0.01$ ) abilities in the miR-21-mimics group were significantly increased and in the miR-21-inhibitor groups were significantly decreased. These findings indicated that miR-21 affected the biological behavior of OC.

miR-21 is involved in the activation of the Wnt signaling pathway and the cytological behavior of $O C$. To further explore the downstream signaling pathway of miR-21, it was ascertained from literature that the Wnt signaling pathway may be one of the primary downstream target genes of miR-21. Therefore, a Wnt inhibitor (XAV-939) and a Wnt agonist (AZD2858) were included in the experiment, and the results were asceertained by qRT-PCR and western blot analysis. As revealed in Fig. 1C, the results indicated that the activation of the Wnt pathway could partly promote the expression of miR-21. Concurrently, the results indicated that the expression of $\mathrm{Wnt} / \beta$-catenin was positively associated with the expression of miR-21 $(\mathrm{P}<0.01)$. The corresponding cell clone formation as well as cell invasion and migration rates were revealed to be associated with the expression level of miR-21. High expression levels of miR-21 promoted the proliferation, migration and invasion of ovarian cancer cells. In the miR-21-mimics groups, the rate of cell clone formation was significantly higher than that of the miR-21-inhibitor group (Fig. $2 \mathrm{C}$ and $\mathrm{D}, \mathrm{P}<0.01$ ), and similar results were obtained in the invasion (Fig. $4 \mathrm{C}$ and $\mathrm{D}, \mathrm{P}<0.01$ ) and migration experiments (Fig. $3 \mathrm{C}$ and $\mathrm{D}, \mathrm{P}<0.01$ ). In addition, the cytological 
A

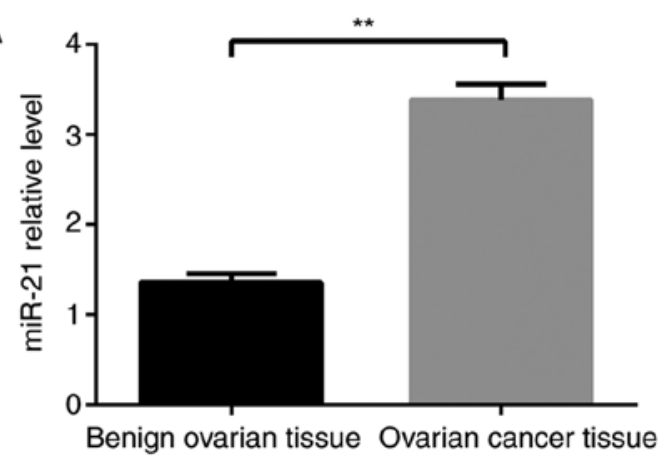

C

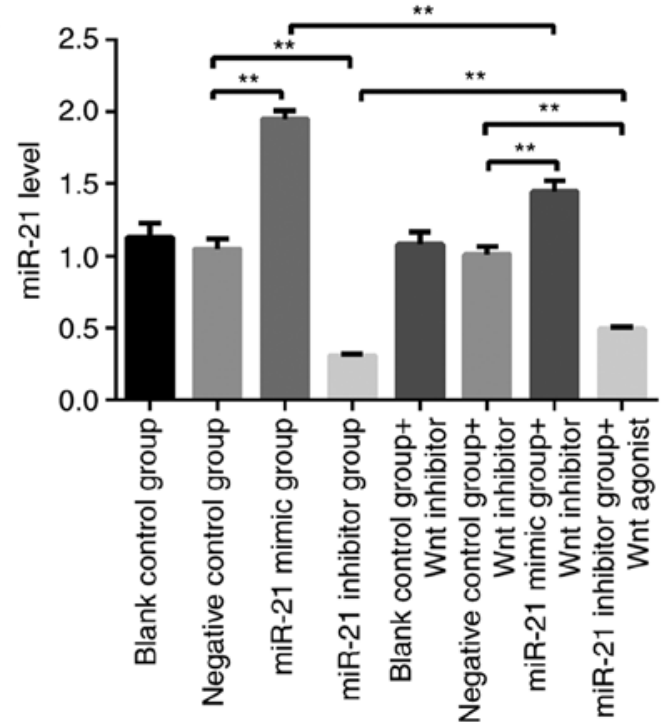

B

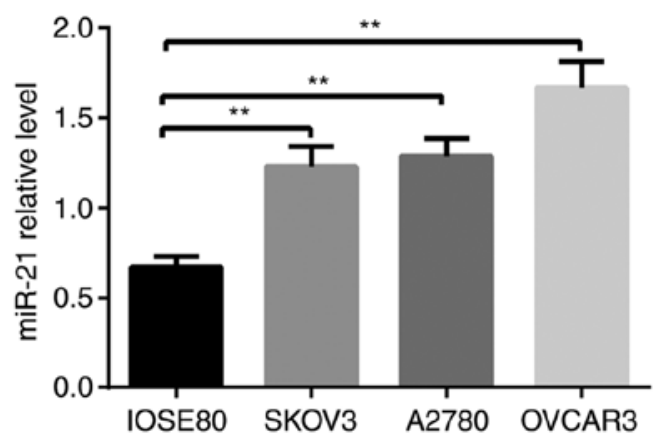

D

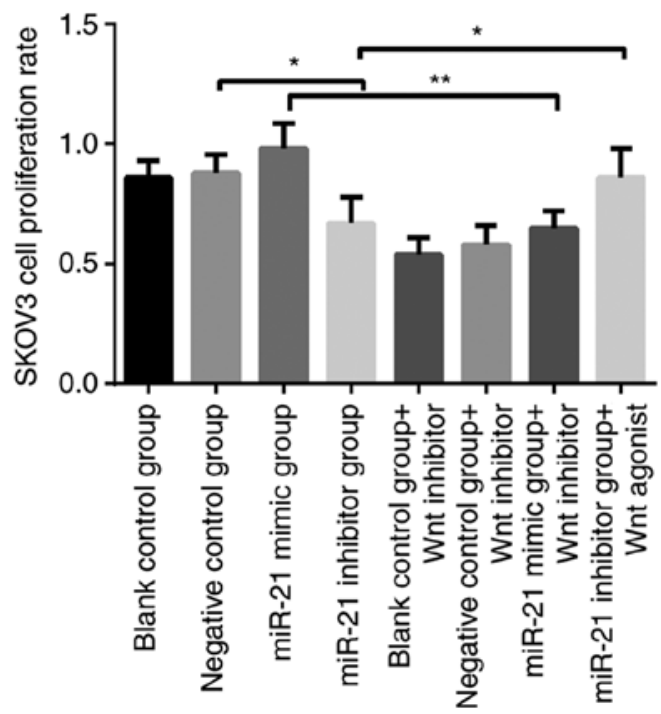

Figure 1. (A) Expression levels of miR-21 in benign ovarian tissues $(n=35)$ and ovarian cancer tissues $(n=40)\left({ }^{* *} \mathrm{P}<0.01\right)$. (B) miR-21expression levels in four different cell lines (SKOV3, A2780, OVCAR3 are ovarian cancer cell lines, and IOSE80 is a normal ovarian epithelial cell line). Compared with IOSE80, the expression of miR-21 was significantly higher in the other three cell lines $\left({ }^{* * *} \mathrm{P}<0.01\right)$. (C) In the OC cell line SKOV3, the expression levels of miR-21 in each group after different treatments ( $\left.{ }^{* *} \mathrm{P}<0.01\right)$. (D) The CCK-8 kit detected the SKOV3 cell proliferation rate at $72 \mathrm{~h}\left({ }^{*} \mathrm{P}<0.05{ }^{* * *} \mathrm{P}<0.01\right)$.

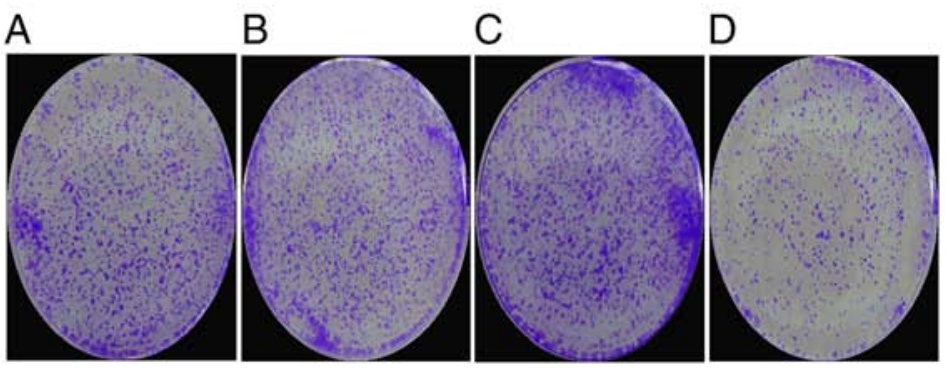

E

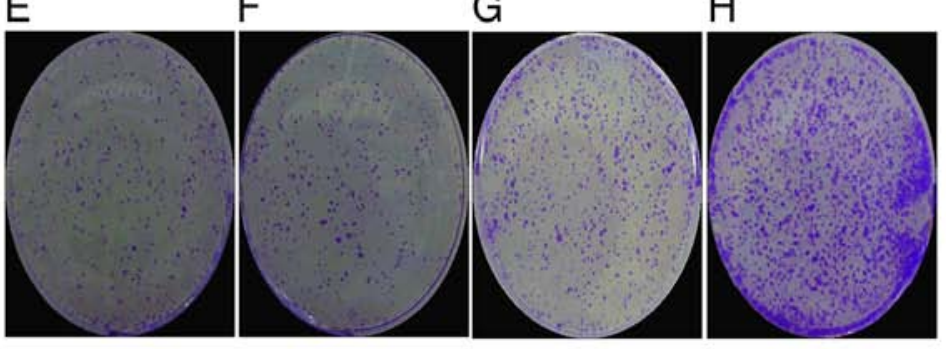

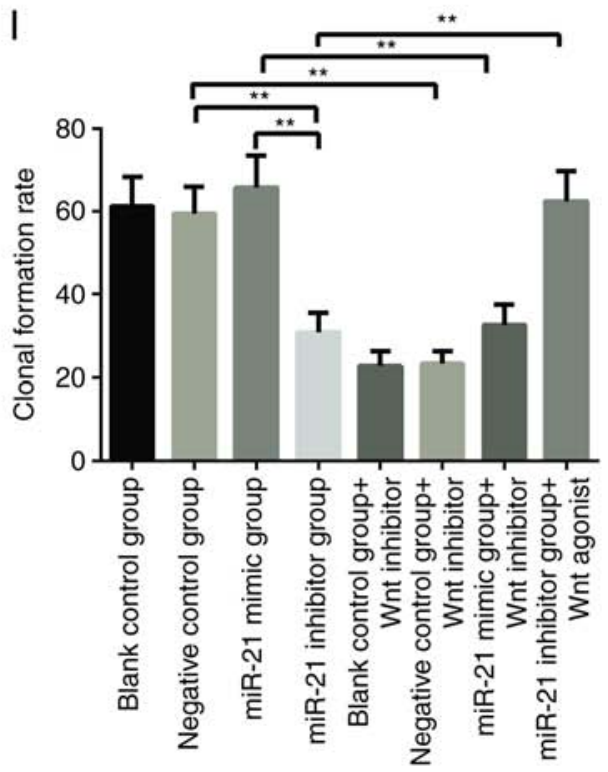

Figure 2. Cell clone proliferation experiments in different groups of SKOV3 ( $\mathrm{n}=3$ ) cells (magnification, $\mathrm{x} 400$ ). (A) Blank control group. (B) Negative control group. (C) miR-21 mimic group. (D) miR-21 inhibitor group. (E) Blank control+Wnt inhibitor group. (F) Negative control+Wnt inhibitor group. (G) miR-21 mimic+Wnt inhibitor group. (H) miR-21 inhibitor+Wnt agonist group. (I) Statistical analysis of the cell clonal formation rate ( $\mathrm{n}=5$ different views) (magnification, $\mathrm{x} 100$ ). The clonal formation rate of cells in the groups specified in $\mathrm{A}, \mathrm{B}, \mathrm{C}$, and $\mathrm{H}$ was significantly higher than that of the other groups. ${ }^{* *} \mathrm{P}<0.01$. 

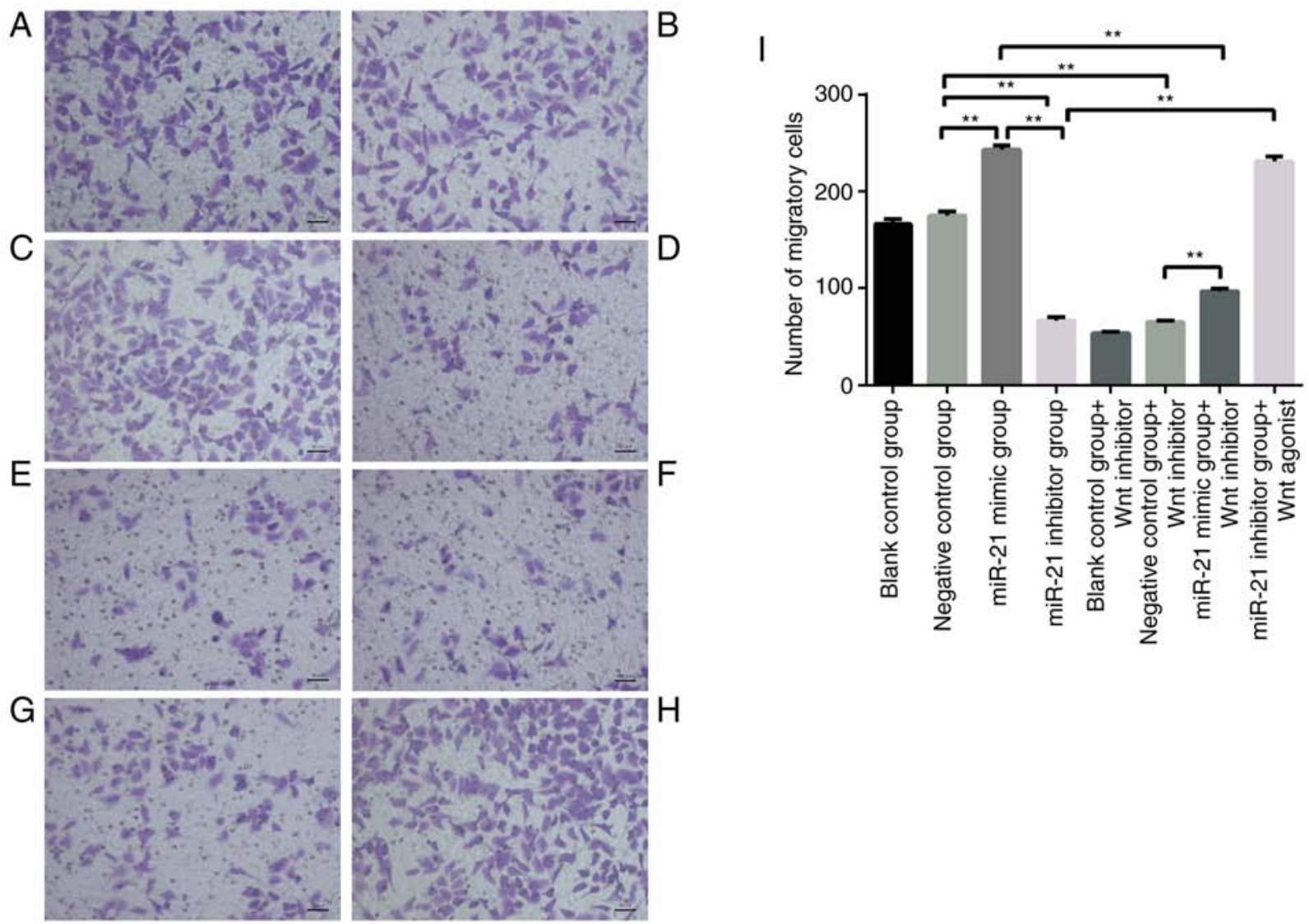

Figure 3. Detection of the cell migration ability in different groups of SKOV3 cells using the Transwell migration method (n=5) (magnification, $\mathrm{x} 400)$. (A) Blank control group. (B) Negative control group; (C) miR-21 mimic group; (D) miR-21 inhibitor group; (E) Blank control+Wnt inhibitor group; (F) Negative control+Wnt inhibitor group; (G) miR-21 mimic+Wnt inhibitor group; (H) miR-21 inhibitor+Wnt agonist group. (I) Statistical analysis of the number of migratory cells ( $\mathrm{n}=5$ different views). ${ }^{* *} \mathrm{P}<0.01$.

behavior was influenced by Wnt/ $\beta$-catenin pathway. When a Wnt inhibitor was added to the miR-21-mimics group, proliferation, migration and invasion of SKOV3 cells were observed to be decreased compared to the miR-21-mimics group alone (Fig. 2C, G and I, P<0.01; Fig. 3C, G and I, $\mathrm{P}<0.01$; Fig. $4 \mathrm{C}, \mathrm{G}$ and $\mathrm{I}, \mathrm{P}<0.01)$. When a Wnt agonist was added in the miR-21-inhibitor group, proliferation, migration and invasion of SKOV3 cells were observed to be increased (Fig. 2D, $\mathrm{H}$ and I, P<0.01; Fig. 3D, $\mathrm{H}$ and I, P<0.01; Fig. 4D, H and $\mathrm{I}, \mathrm{P}<0.01)$. For the expression of $\beta$-catenin mRNA and protein, as observed in Fig. 5, there was no difference between the blank control group and the negative control group. The $\beta$-catenin mRNA and protein expression was significantly higher in the miR-21-mimics group compared with the negative control group (Fig. 5, P<0.01). After treatment with the Wnt inhibitor, the $\beta$-catenin mRNA and protein expression was decreased compared to the miR-21-mimics group alone (Fig. $5, \mathrm{P}<0.01$ ). Since $\beta$-catenin is transferred into the nucleus to promote tumor development, the enucleation of $\beta$-catenin in various groups of miR-21 expression levels was further examined using immunofluorescence. The results revealed that higher expression levels of miR-21 led to the increased enucleation of $\beta$-catenin (Fig. 6). These results indicated that the Wnt signaling pathway could in fact be regulated by miR-21, and moreover, high expression levels of miR-21 activated the Wnt signaling pathway.
The miR-21/Wnt/CD44V6 pathway is involved in the biological behavior of $O C$. Previous studies have confirmed that CD44v6 is highly expressed in OC tissues and cells and that CD44v6 is involved in the development of OC; therefore, this molecule is expected to be a molecular marker for the detection of OC (23). The immunohistochemical results of CD44v6 in our human ovarian benign and malignant tissues were also consistent with this conclusion (Fig. 7A). In addition, studies have reported that the Wnt pathway affects the expression of CD44v6 in tumors (26). Due to the tissue-specific expression of miR-21 and CD44, their molecular regulatory pathways in ovarian cancer are still unclear; thus, the mRNA and protein expression of CD44v6 in different treatment groups were analyzed. The mRNA and protein expression levels of CD44v6 in the miR-21-mimic groups were significantly higher than those in the negative control group $(\mathrm{P}<0.01)$, whereas the mRNA and protein levels of CD44v6 in the miR-21-inhibitor group were significantly lower than those in the negative control group $(\mathrm{P}<0.01)$ (Fig. 7B). These findings indicated that miR-21 affected the expression of CD44v6. To further confirm that miR-21 affects the expression of CD44v6 through the activation of the Wnt signaling pathway, the blank control group, the negative control group and the miR-21 mimics group were treated with a Wnt inhibitor, and a Wnt agonist was added to the miR-21-inhibitor group and the mRNA 

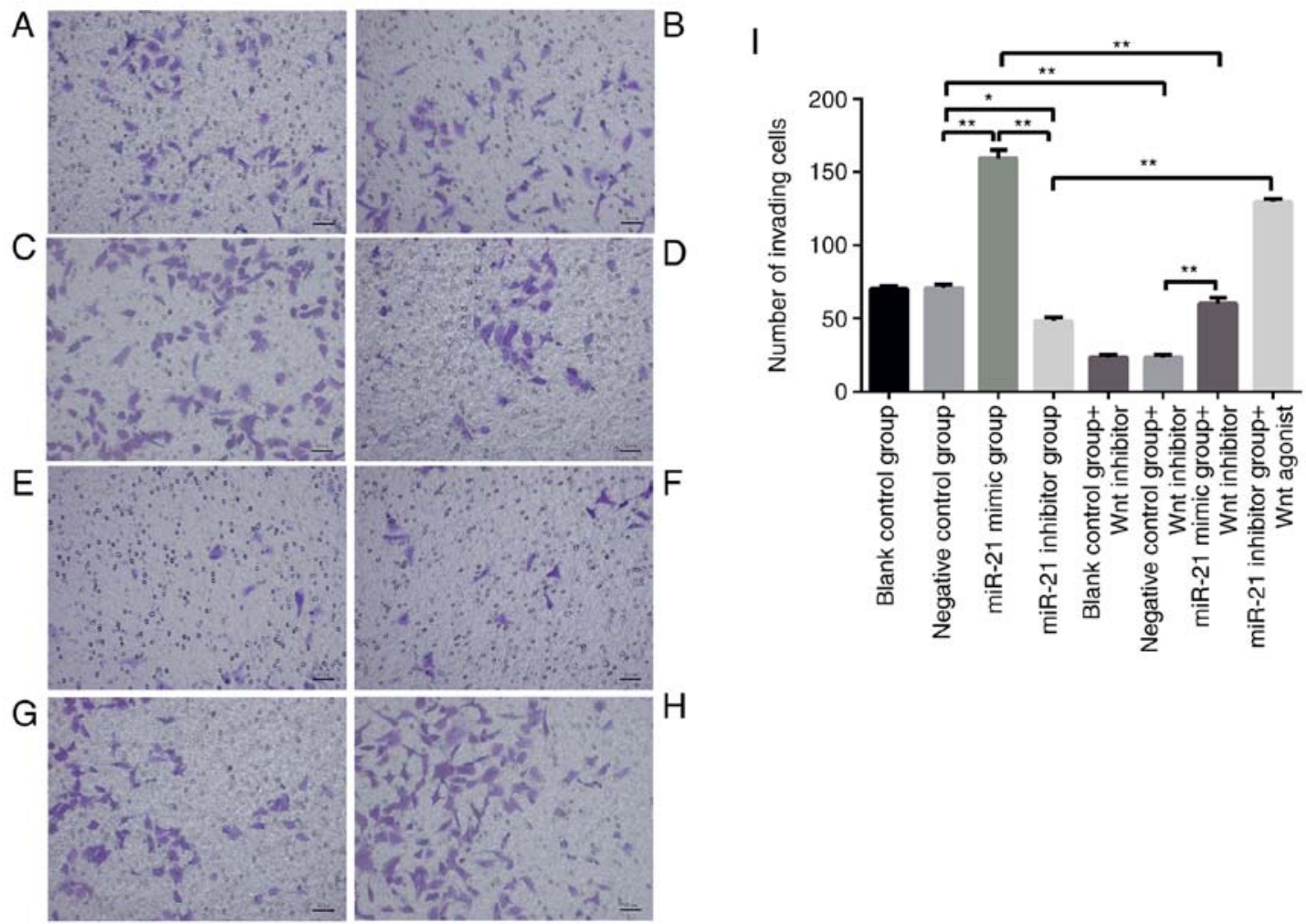

Figure 4. Detection of the cell invasion ability in different groups of SKOV3 cells using the Transwell invasion method (n=5). (A) Blank control group. (B) Negative control group. (C) miR-21 mimic groups. (D) miR-21 inhibitor group. (E) Blank control+Wnt inhibitor group. (F) Negative control+Wnt inhibitor group. (G) miR-21 mimic $+W n t$ inhibitor groups. (H) miR-21 inhibitor+Wnt agonist group. (I) Statistical analysis of the number of invading cells ( $\mathrm{n}=5$ different views). ${ }^{*} \mathrm{P}<0.05$; ${ }^{* *} \mathrm{P}<0.01$.

A

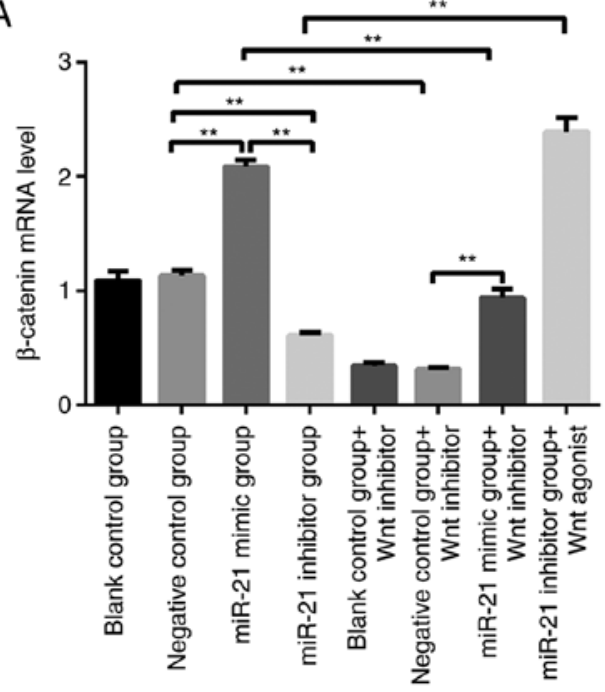

B

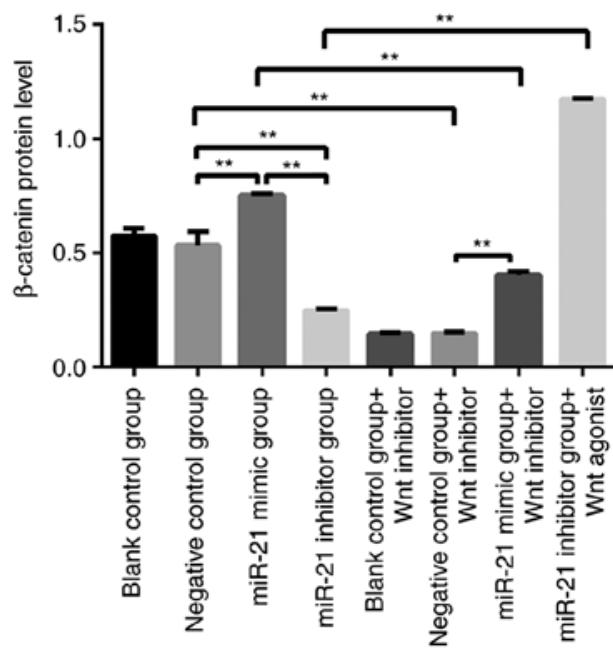

C

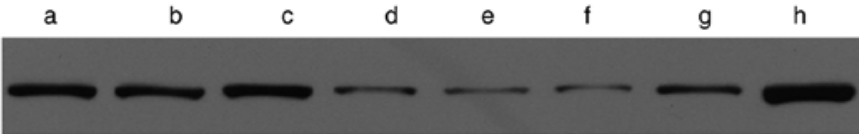

GAPDH

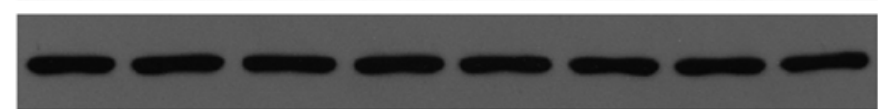

Figure 5. (A) mRNA expression levels of $\beta$-catenin in each group after different treatments $\left.{ }^{(* *} \mathrm{P}<0.01\right)$. The mRNA expression level of $\beta$-catenin was significantly higher in the miR-21-mimic group than that in the blank control group. In addition, the mRNA expression level of $\beta$-catenin was significantly lower in the miR-21 inhibitor group than that in the blank control group. (B and C) Relative quantitative analysis of the expression bands of each group of proteins and western blot analysis of $\beta$-catenin protein expression in different treatment groups. The protein expression level of $\beta$-catenin was significantly higher in the miR-21-mimic group than that in the blank control group. In addition, the protein expression level of $\beta$-catenin was significantly lower in the miR-21-inhibitor group than that in the blank control group. ( $\left.{ }^{* *} \mathrm{P}<0.01\right)$. (C) a, blank control group; b, negative control group; c, miR-21-mimic group; d, miR-21-inhibitor group; e, blank control group+Wnt inhibitor; f, negative control group+Wnt inhibitor; g, miR-21-mimic group+Wnt inhibitor; h, miR-21-inhibitor group+Wnt agonist . 

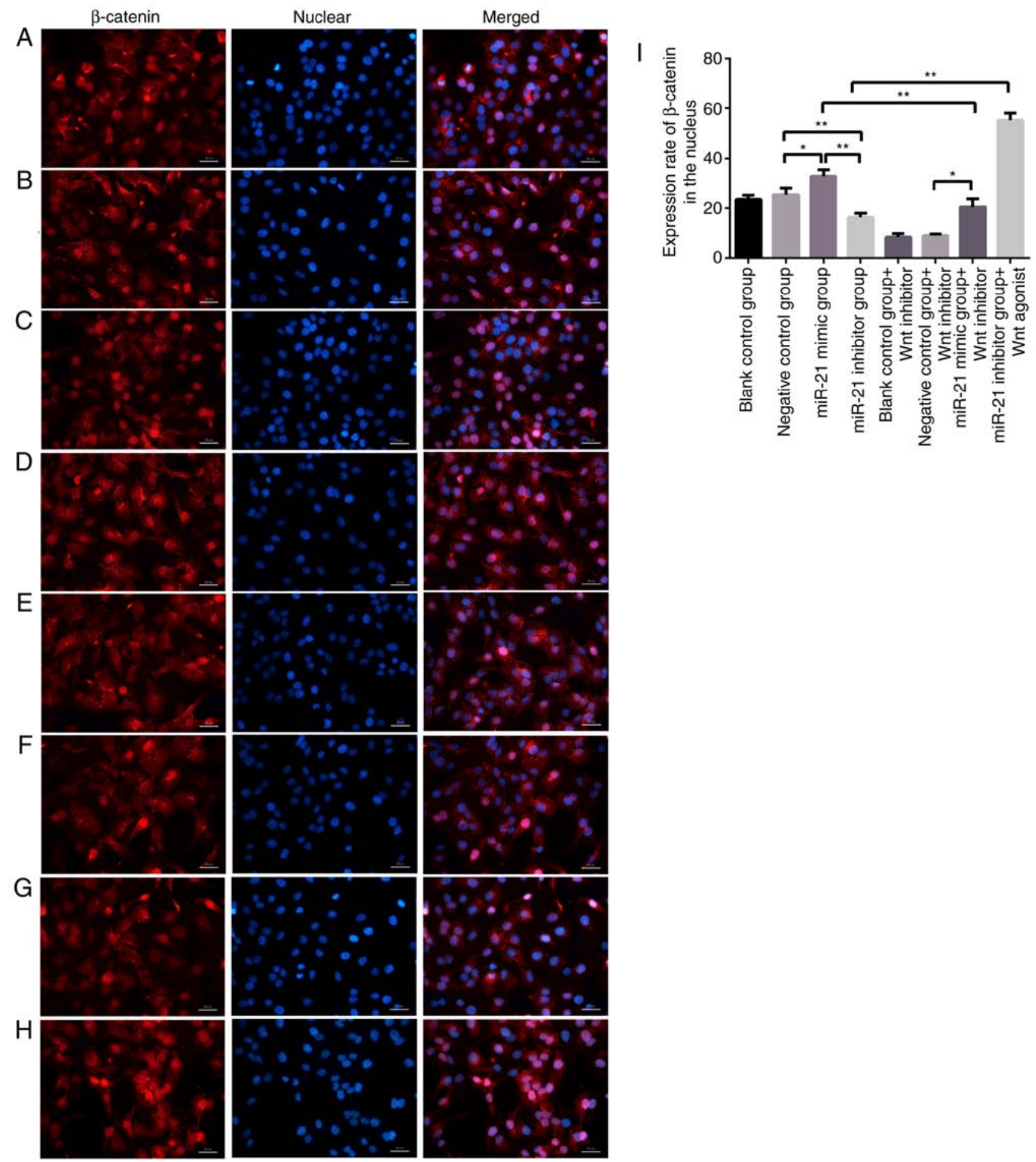

Figure 6. Immunofluorescence was used to detect the entry of $\beta$-catenin into the nucleus. Red represents the expression of $\beta$-catenin, and blue represents the nucleus. (A) Blank control group; (B) Negative control group; (C) miR-21 mimic group; (D) miR-21 inhibitor group; (E) Blank control+Wnt inhibitor group; (F) Negative control+Wnt inhibitor group; (G) miR-21 mimic+Wnt inhibitor group; (H) miR-21 inhibitor+Wnt agonist group. (x400, magnification). (I) Quantification of the level of nuclear localization of $\beta$-catenin. ${ }^{*} \mathrm{P}<0.05 ;{ }^{* *} \mathrm{P}<0.01$

and protein expression levels of CD44v6 were reanalyzed. The expression of CD44v6 was revealed to be significantly lower following the addition of the Wnt inhibitor, whereas the expression of CD44v6 in the Wnt agonist group was significantly increased compared to the miR-21-mimics group alone (Fig. 7B and D). These findings indicated that the miR-21/Wnt/CD44v6 axis plays an important role in the development of OC.

\section{Discussion}

miR-21 has been revealed to be involved in the development of a variety of tumors, including liver, gastric, non-small cell lung and breast cancer, as well as neurological tumors and esophageal cancer $(27,28)$. It has been suggested that miR-21 may play an oncogenic role in tumors (29). However, the role of miR-21 in OC is still controversial, although this miRNA 
A

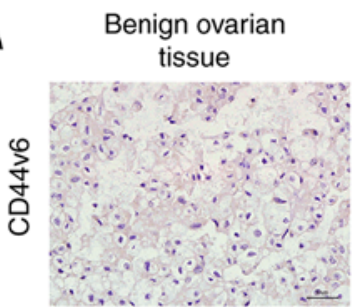

Ovarian malignant tumor tissue

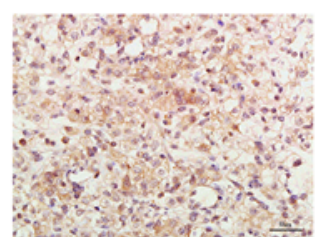

B

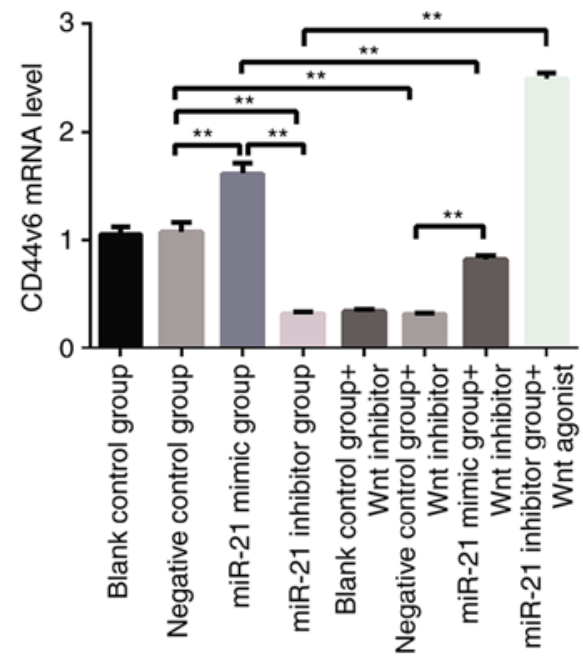

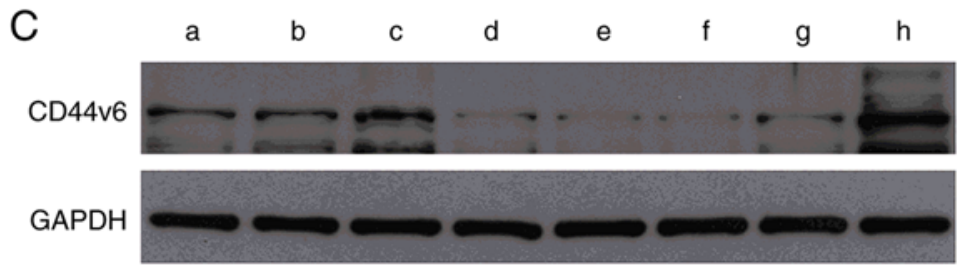

D

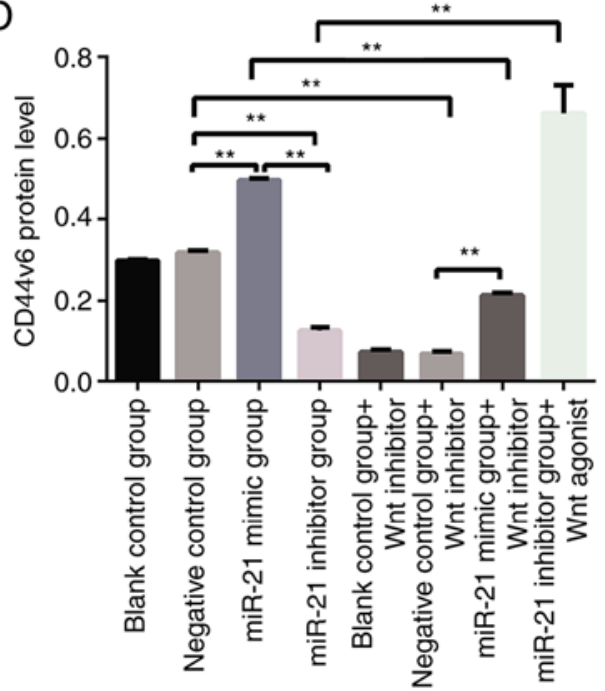

Figure 7. (A) The protein expression of CD44v6 in benign ovarian tissues and ovarian cancer tissues was detected by immunohistochemistry (x400, magnification). Yellow-brown represents the positive expression of CD44v6, localized in the envelope. (B) mRNA expression levels of CD44v6 in each group after different treatments $\left({ }^{* *} \mathrm{P}<0.01\right)$. The mRNA expression level of CD44v6 was significantly higher in the miR-21-mimic groups than that in the blank control group. In addition, the mRNA expression level of CD44v6 was significantly lower in the miR-21-inhibitor group than that in the blank control group $\left(^{* *} \mathrm{P}<0.01\right)$. (C) Western blot analysis of CD44v6 protein expression in different treatment groups. a, blank control group; b, negative control group; c, miR-21-mimic group; d, miR-21-inhibitor group; e, blank control group+Wnt inhibitor; f, negative control group+Wnt inhibitor; g, miR-21-mimic group+Wnt inhibitor; $\mathrm{h}$, miR-21-inhibitor group+Wnt agonist (D) Relative quantitative analysis of the expression bands of each group of proteins. The protein expression level of CD44v6 was significantly higher in the miR-21-mimic group than that in the blank control group. In addition, the protein expression level of CD44v6 was significantly lower in the miR-21-inhibitor group than that in the blank control group $\left({ }^{* *} \mathrm{P}<0.01\right)$.

is typically upregulated in OC (30). In the present study, a significant increase in miR-21 expression in malignant OC tissues was demonstrated. Furthermore, it was confirmed in cell experiments that a high expression of miR-21 promoted the proliferation/invasion/migration of SKOV3 cells, and the inhibition of miR-21 expression reduced the invasion/migration and metastasis of SKOV3 cells (Figs. 2-4).

The Wnt/ $\beta$-catenin signal transduction pathway has been extremely conserved throughout biological evolution. In normal somatic cells, $\beta$-catenin acts as a cytoskeletal protein at the cell membrane to form a complex with E-cadherin to maintain adhesion among cells of the same type and to prevent cell migration (31). When the extracellular Wnt signaling molecule binds to the specific receptor Frizzled protein on the cell membrane to activate the intracellular disheveled protein, GSK3B is inactivated, which prevents $\beta$-catenin from being phosphorylated and degraded (32). $\beta$-catenin can accumulate in the cytoplasm, and when the cytoplasmic concentration of $\beta$-catenin reaches a certain level, $\beta$-catenin can be transferred to the nucleus. In the nucleus, $\beta$-catenin binds to the transcription factor family TCF/LEFs, which activates protooncogenes such as cyclin D1 and c-Myc, leading to cell proliferation, differentiation and maturation (32). Some researchers have studied the effect of miR-21 on the Wnt signaling pathway by stably transfecting miR-21-overexpressing HCT-116 cells. Their results indicated that miR-21 overexpression leads to the activation of Wnt/ $\beta$-catenin signaling, such as decreased levels of axin (a negative regulator of the Wnt signaling pathway), increased levels of $\beta$-catenin, the induction of TCF/LEF (a group of transcription factors that bind to DNA through a high-mobility group domain and are involved in the Wnt signaling pathway) activity, and the increased expression of 
the downstream target proteins c-Myc and cyclin D1 (32-36). These conclusions are consistent with our present results. $\mathrm{Yu}$ et al (37) demonstrated that miR-21 induces stemness of colon cancer cells by activating the $\mathrm{Wnt} / \beta$-catenin pathway, which is mediated through the downregulation of TGF $\beta R 2$. Wu et al (38) studied miR-21 in lung cancer cells and revealed that in A549 human lung cancer cells and Lewis lung carcinoma in mice, the key molecules $\beta$-catenin and cyclin D1 and the $\mathrm{Wnt} / \beta$-catenin signaling pathway were positively correlated. In the present study, in OC cells, the addition of a miR-21 mimics activated the Wnt signaling pathway, whereas the addition of a miR-21 inhibitor blocked the Wnt signaling pathway (Figs. 5 and 6). Unfortunately, we failed to identify the target gene of miR-21 in ovarian cancer cells that directly or indirectly activates the $\mathrm{Wnt} / \beta$-catenin signaling pathway. Studies have revealed that the TGF- $\beta$ signaling pathway is significantly activated in advanced epithelial ovarian cancer (39), which is in contrast to the inhibition of TGF- $\beta$ receptors that occurs in colon cancer cells. Therefore, in future studies, we will focus on identifying target genes of miR-21 that specifically activate the Wnt/ $\beta$-catenin signaling pathway in ovarian cancer cells.

The primary role of CD44v6 is to promote cell migration and invasion, and the expression of CD44v6 in malignant ovarian tissue was revealed to be significantly increased (Fig. 7A). Studies have revealed that CD44v6 is a prominent target molecule of the Wnt signaling pathway (40). Our experiments in the $\mathrm{OC}$ cell line further demonstrated that the inhibition of the Wnt signaling pathway leads to a decrease in the malignancy of OC cells, a decrease in invasiveness, and a significant decrease in the mRNA and protein expression of CD44v6 (Fig. 7B-D); after the inhibitory effects wore off, the degree of malignancy of OC cells increased, the invasiveness increased, and the mRNA and protein expression of CD44v6 also significantly increased (Fig. 7B and C). Similar results have been demonstrated in other tumor studies. Wielenga et al (41) demonstrated that CD44v6 expression is downstream of Wnt signaling and was induced by the $\beta$-catenin/Tcf- 4 signaling pathway. The expression of CD44v6 was increased in colorectal cancer stem cells by the activation of the Wnt/ $\beta$-catenin pathway, which promoted cell migration and metastasis. Certain articles have reported that $\beta$-catenin can regulate CD44v6 expression. Sun et al revealed that Biejiajian Pills can significantly reduce the expression of $\beta$-catenin by decreasing the phosphorylation of GSK-3 $\beta$ and blocking the $\mathrm{Wnt} / \beta$-catenin signaling pathway to cause downregulation of the target genes CD44v6 and VEGF, which may be one of the molecular mechanisms by which Biejiajian Pills suppress the proliferation and invasiveness of hepatocellular carcinoma (26). In addition, Todaro et al revealed that cytokine hepatocyte growth factor (HGF), osteopontin (OPN), and stromal-derived factor $1 \alpha$ (SDF-1), secreted from tumor-associated cells, increased CD44v6 expression in CR-CSCs by activating the $\mathrm{Wnt} / \beta$-catenin pathway, which promoted migration and metastasis (42). In addition, Han et al (43) determined that the siRNA-mediated downregulation of $\beta$-catenin markedly inhibited the invasion and migration of LoVo cells, which may be related to the upregulation of E-cadherin and the reduction of CD44v6 and MMP-7 in these cells. However, in the 'miR-21 mimic+wnt inhibitor' groups, the miR-21 mimics partially rescued CD44v6 expression. There may exist Wnt-independent mechanisms that could also be implicated in the miR-21-dependent regulation of CD44v6. CD44 progenitor cells do not confer metastatic capacity to the cells, but when treated with cytokines to express CD44v6, the cells gain metastatic potential. Moreover, a higher survival rate was detected in patients with low expression of CD44v6 compared with patients with high expression. Therefore, the authors surmised that the metastatic process of colon cancer is initiated by the expression of CD44v6 by cancer stem cells, indicating that CD44v6 is both a functional biomarker and a therapeutic target (44). In ovarian cancer, CD $44^{+} / \mathrm{CD} 117^{+}$ cancer stem cells exhibit a strong proliferative capacity, a low degree of differentiation, and increased resistance to chemotherapy drugs. These cells also predict a poor prognosis (44). However, CD44v6 is a membrane protein molecule that can transduce a variety of molecular signaling pathways. This raises the question of which molecules mediate the effects of CD44v6 on the biological behavior of ovarian cancer. We studied this issue further, and it was determined that CD44v6 affects the biological behavior of ovarian cancer through the $\mathrm{NF}-\kappa \mathrm{B}$ pathway.

In conclusion, the present study revealed that miR-21 regulates the expression of CD44v6 by activating the Wnt signaling pathway, which plays an important role in the development of ovarian cancer. These findings provide a potential new therapeutic target for the clinical diagnosis and treatment of ovarian cancer.

\section{Acknowledgements}

Not applicable.

\section{Funding}

The present study was funded by the Chinese Medical Association Clinical Medical Research Special Fund Project (Award no. 17020310700) and the Wuhan University Independent Research Project (Award no. 413000117).

\section{Availability of data and materials}

All datasets on which the conclusions of the paper depend are available to readers.

\section{Authors' contributions}

YC supervised the project. YW participated in the fund raising, experimental design, data acquisition, and article writing. MY performed the majority of the experiments and drafted the manuscript. LZ and XY participated in the fund raising and collected clinical specimens. DY designed and supervised the in vitro functional study. SX supervised the results. YW performed the preliminary experiments. YC was a major contributor in the revision of the manuscript. All authors were involved in the conception of the study, read and approved the manuscript and agree to be accountable for all aspects of the research in ensuring that the accuracy or integrity of any part of the work are appropriately investigated and resolved. 


\section{Ethics approval and consent to participate}

All procedures performed and all clinical data obtained in the present study involving human participants were reviewed and approved by the Medical Ethics Committee of Renmin Hospital of Wuhan University and were in accordance with the 1964 Helsinki declaration and its later amendments or comparable ethical standards. Informed consent was obtained from all individual participants included in the study.

\section{Patient consent for publication}

Not applicable.

\section{Competing interests}

The authors declare that they have no competing interests.

\section{References}

1. Torre LA, Trabert B, DeSantis CE, Miller KD, Samimi G, Runowicz CD, Gaudet MM, Jemal A and Siegel RL: Ovarian cancer statistics, 2018. CA Cancer J Clin 68: 284-296, 2018.

2. Wu J, Sun H, Yang L, Deng Y, Yan Y, Wang S, Yang G and Ma H: Improved survival in ovarian cancer, with widening survival gaps of races and socioeconomic status: A period analysis, 1983-2012. J Cancer 9: 3548-3556, 2018

3. Bartel DP: MicroRNAs: Genomics, biogenesis, mechanism, and function. Cell 116: 281-297, 2004.

4. Yang N, Kaur S, Volinia S, Greshock J, Lassus H, Hasegawa K, Liang S, Leminen A, Deng S, Smith L, et al: MicroRNA microarray identifies Let-7i as a novel biomarker and therapeutic target in human epithelial ovarian cancer. Cancer Res 68: 10307-10314, 2008.

5. Yu SL, Chen HY, Chang GC, Chen CY, Chen HW, Singh S, Cheng CL, Yu CJ, Lee YC, Chen HS, et al: MicroRNA signature predicts survival and relapse in lung cancer. Cancer Cell 13: 48-57, 2008.

6. Weidhaas JB, Babar I, Nallur SM, Trang P, Roush S, Boehm M, Gillespie E and Slack FJ: MicroRNAs as potential agents to alter resistance to cytotoxic anticancer therapy. Cancer Res 67: 11111-11116, 2007.

7. Bentwich I, Avniel A, Karov Y, Aharonov R, Gilad S, Barad O, Barzilai A, Einat P, Einav U, Meiri E, et al: Identification of hundreds of conserved and nonconserved human microRNAs. Nat Genet 37: 766-770, 2005.

8. Backes C and Keller A: Reanalysis of 3,707 novel human microRNA candidates. Proc Natl Acad Sci USA 112: E2849-E2850, 2015.

9. Volinia S, Calin GA, Liu CG, Ambs S, Cimmino A, Petrocca F, Visone R, Iorio M, Roldo C, Ferracin M, et al: A microRNA expression signature of human solid tumors defines cancer gene targets. Proc Natl Acad Sci USA 103: 2257-2261, 2006

10. Chan JA, Krichevsky AM and Kosik KS: MicroRNA-21 is an antiapoptotic factor in human glioblastoma cells. Cancer Res 65: 6029-6033, 2005.

11. Nusse R, Fuerer C, Ching W, Harnish K, Logan C, Zeng A, ten Berge D and Kalani Y: Wnt signaling and stem cell control. Cold Spring Harb Symp Quant Biol 73: 59-66, 2008.

12. Valenta T, Hausmann $G$ and Basler K: The many faces and functions of $\beta$-catenin. EMBO J 31: 2714-2736, 2012.

13. Liu J, Pan S, Hsieh MH, Ng N, Sun F, Wang T, Kasibhatla S, Schuller AG, Li AG, Cheng D, et al: Targeting Wnt-driven cancer through the inhibition of Porcupine by LGK974. Proc Natl Acad Sci USA 110: 20224-20229, 2013.

14. Arend RC,Londoño-Joshi AI, Straughn JM Jr and Buchsbaum DJ: The Wnt/B-catenin pathway in ovarian cancer: A review. Gynecol Oncol 131: 772-779, 2013.

15. Cai X, Yao Z, Li L and Huang J: Role of DKK4 in Tumorigenesis and Tumor Progression. Int J Biol Sci 14: 616-621, 2018

16. Chau WK, Ip CK, Mak AS, Lai HC and Wong AS: c-Kit mediates chemoresistance and tumor-initiating capacity of ovarian cancer cells through activation of Wnt/ $\beta$-catenin-ATP-binding cassette G2 signaling. Oncogene 32: 2767-2781, 2013.
17. Nagel R, le Sage C, Diosdado B, van der Waal M, Oude Vrielink JA, Bolijn A, Meijer GA and Agami R: Regulation of the adenomatous polyposis coli gene by the miR-135 family in colorectal cancer. Cancer Res 68: 5795-5802, 2008.

18. Luo G, Luo W, Sun X, Lin J, Wang M, Zhang Y, Luo W and Zhang Y: MicroRNA21 promotes migration and invasion of glioma cells via activation of Sox 2 and $\beta$-catenin signaling. Mol Med Rep 15: 187-193, 2017.

19. Günthert U, Hofmann M, Rudy W, Reber S, Zöller M, Haussmann I, Matzku S, Wenzel A, Ponta $\mathrm{H}$ and Herrlich P: A new variant of glycoprotein CD44 confers metastatic potential to rat carcinoma cells. Cell 65: 13-24, 1991.

20. Rudy W, Hofmann M, Schwartz-Albiez R, Zöller M, Heider KH, Ponta $\mathrm{H}$ and Herrlich P: The two major CD44 proteins expressed on a metastatic rat tumor cell line are derived from different splice variants: Each one individually suffices to confer metastatic behavior. Cancer Res 53: 1262-1268, 1993.

21. Seiter S, Arch R, Reber S, Komitowski D, Hofmann M, Ponta H, Herrlich P, Matzku S and Zöller M: Prevention of tumor metastasis formation by anti-variant CD44. J Exp Med 177: 443-455, 1993.

22. Tjhay F, Motohara T, Tayama S, Narantuya D, Fujimoto K, Guo J, Sakaguchi I, Honda R, Tashiro H and Katabuchi H: CD44 variant 6 is correlated with peritoneal dissemination and poor prognosis in patients with advanced epithelial ovarian cancer. Cancer Sci 106: 1421-1428, 2015.

23. Motohara T, Fujimoto K, Tayama S, Narantuya D, Sakaguchi I, Tashiro $\mathrm{H}$ and Katabuchi $\mathrm{H}$ : CD44 variant 6 as a predictive biomarker for distant metastasis in patients with epithelial ovarian cancer. Obstet Gynecol 127: 1003-1011, 2016.

24. Katoh M: Multilayered prevention and treatment of chronic inflammation, organ fibrosis and cancer associated with canonical WNT/ $\beta$-catenin signaling activation (Review). Int J Mol Med 42: 713-725, 2018

25. Livak KJ and Schmittgen TD: Analysis of relative gene expression data using real-time quantitative PCR and the 2(-Delta Delta $\mathrm{C}(\mathrm{T})$ ) method. Methods 25: 402-408, 2001

26. Sun H, He S, Wen B, Jia W, Fan E and Zheng Y: Effect of Biejiajian Pills on Wnt signal pathway molecules $\beta$-catenin and GSK-3 $\beta$ and the target genes CD44v6 and VEGF in hepatocellular carcinoma cells. Nan Fang Yi Ke Da Xue Xue Bao 34: 1454-1458, 2014 (In Chinese).

27. Kumarswamy R, Volkmann I and Thum T: Regulation and function of miRNA-21 in health and disease. RNA Biol 8: 706-713, 2011.

28. Bonci D: MicroRNA-21 as therapeutic target in cancer and cardiovascular disease. Recent Pat Cardiovasc Drug Discov 5: 156-161, 2010.

29. Huang Y, Yang YB, Zhang XH, Yu XL, Wang ZB and Cheng XC: MicroRNA-21 gene and cancer. Med Oncol 30: 376, 2013.

30. Vaksman O, Tropé C, Davidson B and Reich R: Exosome-derived miRNAs and ovarian carcinoma progression. Carcinogenesis 35 : 2113-2120, 2014

31. Kimura M, Nakajima-Koyama M, Lee J and Nishida E: Transient expression of WNT2 promotes somatic cell reprogramming by inducing $\beta$-catenin nuclear accumulation. Stem Cell Reports 6 : 834-843, 2016.

32. Zhan T, Rindtorff $\mathrm{N}$ and Boutros $\mathrm{M}$ : Wnt signaling in cancer. Oncogene 36: 1461-1473, 2017.

33. Echevarría-Vargas IM, Valiyeva $F$ and Vivas-Mejía PE: Upregulation of miR-21 in cisplatin resistant ovarian cancer via JNK-1/c-Jun pathway. PLoS One 9: e97094, 2014.

34. Zhang H, Li J, Li G and Wang S: Effects of celastrol on enhancing apoptosis of ovarian cancer cells via the downregulation of microRNA21 and the suppression of the PI3K/AktNF-kB signaling pathway in an in vitro model of ovarian carcinoma. Mol Med Rep 14: 5363-5368, 2016.

35. Eitan R, Kushnir M, Lithwick-Yanai G, David MB, Hoshen M, Glezerman M, Hod M, Sabah G, Rosenwald S and Levavi H: Tumor microRNA expression patterns associated with resistance to platinum based chemotherapy and survival in ovarian cancer patients. Gynecol Oncol 114: 253-259, 2009.

36. Cevallos RR, Rodríguez-Martínez G and Gazarian K: $\mathrm{Wnt} / \beta$-catenin/TCF pathway is a phase-dependent promoter of colony formation and mesendodermal differentiation during human somatic cell reprogramming. Stem Cells 36: 683-695, 2018.

37. Yu Y, Kanwar SS, Patel BB, Oh PS, Nautiyal J, Sarkar FH and Majumdar AP: MicroRNA-21 induces stemness by downregulating transforming growth factor beta receptor 2 (TGF $\beta R 2)$ in colon cancer cells. Carcinogenesis 33: 68-76, 2012. 
38. Wu D, Shi M and Fan XD: Mechanism of miR-21 viaWnt/ $\beta$-catenin signaling pathway in human A549 lung cancer cells and Lewis lung carcinoma in mice. Asian Pac J Trop Med 8: 479-484, 2015.

39. Yamamura S, Matsumura N, Mandai M, Huang Z, Oura T, Baba T, Hamanishi J, Yamaguchi K, Kang HS, Okamoto T, et al: The activated transforming growth factor-beta signaling pathway in peritoneal metastases is a potential therapeutic target in ovarian cancer. Int J Cancer 130: 20-28, 2012.

40. SchmittM,MetzgerM,GradlD,Davidson G and Orian-Rousseau V: CD44 functions in Wnt signaling by regulating LRP6 localization and activation. Cell Death Differ 22: 677-689, 2015.

41. Wielenga VJ, van der Neut R, Offerhaus GJ and Pals ST: CD44 glycoproteins in colorectal cancer: Expression, function, and prognostic value. Adv Cancer Res 77: 169-187, 2000.
42. Todaro M, Gaggianesi M, Catalano V, Benfante A, Iovino F Biffoni M, Apuzzo T, Sperduti I, Volpe S, Cocorullo G, et al: CD44v6 is a marker of constitutive and reprogrammed cancer stem cells driving colon cancer metastasis. Cell Stem Cell 14: 342-356, 2014.

43. Han J, Gao B, Jin X, Xu Z, Li Z, Sun Y and Song B: Small interfering RNA-mediated downregulation of beta-catenin inhibits invasion and migration of colon cancer cells in vitro. Med Sci Monit 18: BR273-BR280, 2012.

44. Gao Y, Foster R, Yang X, Feng Y, Shen JK, Mankin HJ, Hornicek FJ, Amiji MM and Duan Z: Up-regulation of CD44 in the development of metastasis, recurrence and drug resistance of ovarian cancer. Oncotarget 6: 9313-9326, 2015. c) (i) (9) This work is licensed under a Creative Commons International (CC BY-NC-ND 4.0) License. 